\title{
PENGAWETAN PINDANG IKAN LAYANG (Decapterus russelli) MENGGUNAKAN KITOSAN
}

\author{
Farida Ariyani*) dan Yusma Yennie*)
}

\begin{abstract}
ABSTRAK
Studi tentang pengawetan pindang ikan layang menggunakan kitosan telah dilakukan. Bahan baku yang digunakan dalam penelitian ini adalah ikan layang (Decapterus russelli) segar yang diperoleh dari TPI Pelabuhan Ratu hasil penangkapan satu hari melaut. Ikan layang dibawa ke laboratorium BBRP2B menggunakan jalan darat dalam peti es berinsulasi dan diolah menjadi pindang 'naya' dengan perebusan dalam air garam $15 \%$ selama 15 menit. Pindang layang yang dihasilkan kemudian dibagi menjadi 3 kelompok yang masing-masing dicelupkan dalam larutan kitosan dengan konsentrasi berturut-turut $0 ; 0,25$; dan $0,50 \%(\mathrm{~b} / \mathrm{v})$ selama 30 menit. Selesai perendaman, naya berisi ikan ditiriskan dan disimpan pada suhu kamar. Untuk melihat perubahan kualitas pindang selama penyimpanan, dilakukan pengambilan sampel setiap hari sampai pindang naya tersebut ditolak oleh panelis. Pengamatan terhadap sampel dilakukan secara organoleptik (kenampakan, bau, rasa, tekstur, dan pembentukan lendir), kimiawi (TVB) maupun mikrobiologi (TPC, bakteri pembentuk $\mathrm{H}_{2} \mathrm{~S}$ ). Hasil percobaan menunjukkan bahwa kitosan mempunyai potensi untuk memperpanjang daya awet pindang layang. Daya awet pindang yang dicelup kitosan adalah 3 hari pada penyimpanan suhu kamar, sedangkan daya awet pindang kontrol hanya 1 hari.
\end{abstract}

\section{ABSTRACT: Preservation of boiled salted scad mackerel (Decapterus russelli) using chitosan. By: Farida Ariyani and Yusma Yennie}

Studies on the preservation of boiled salted mackerel (Decapterus russelli) using chitosan have been done. Raw materials used in this study were fresh scad mackerel (Decapterus russelli) obtained from Fish Auction Place in Pelabuhan Ratu derived from one day fishing. Fresh scad mackerel was transported in insulated box filled with crushed ice to the RCMFP2B Laboratory. On arrival in the laboratory, fresh scad mackerel were processed into 'naya' boiled salted products by boiling them in $15 \%$ brine solution for 15 minutes. Boiled salted scad mackerel produced was then divided into 3 groups and each group was dipped in chitosan solution with concentration of 0 , 0.25 and $0.50 \%$ (w/V) for 30 minutes, drained and stored at ambient temperature. Quality changes of boiled salted scad during storage was monitored daily, including sensory evaluation (appearance, odour, taste, texture and slime formation), chemical (TVB) and microbiological (TPC, $\mathrm{H}_{2} \mathrm{~S}$ forming bacteria) characteristics, until rejected by panelists. Results of the studies showed that chitosan has good potential to prolong the shelf-life of boiled salted scad. The shelf life of boiled salted scad dipped in chitosan solution and stored at ambient temperature was 3 days, whereas the shelflife of similar product without chitosan treatment was only 1 day.

\section{KEYWORDS: $\quad$ boiled salted fish, scad mackerel, chitosan, preservatives}

\section{PENDAHULUAN}

Ikan pindang merupakan salah satu produk olahan ikan tradisional yang sangat populer dan banyak disukai oleh masyarakat Indonesia. Berdasarkan urutan disposisi dalam pengolahan tradisional, produk pindang menduduki posisi ke 2 setelah produk ikan asin (Anon., 2006). Beberapa jenis pindang yang tersedia di pasar adalah pindang presto, pindang 'badeng' atau 'paso' dan pindang 'naya' atau 'cue'. Pindang presto merupakan jenis pindang yang pada umumnya dibuat dari ikan bandeng, berduri lunak, dan paling awet karena dalam pembuatannya menggunakan pemanas bertekanan (autoclave) dan dikemas dalam kantung plastik hampa udara/vakum.
Pindang jenis ini biasa dijajakan di pasar swalayan. Produk pindang 'badeng' atau 'paso' pada umumnya dibuat dari ikan tongkol, dan pindang naya biasanya diolah dari ikan layang atau lemuru yang dipasarkan di pasar tradisional dengan ditempatkan dalam paso atau naya dalam keadaan terbuka, sehingga memungkinkan terjadinya kontaminasi mikroba selama proses penjualan. Karena kadar garamnya relatif kecil dan kadar airnya yang masih cukup tinggi, daya tahan pindang "naya" sangat pendek yaitu berkisar 1-3 hari (Nasran, 1980) atau 2-7 hari (Gopakumar, 1997) tergantung pada jenis ikannya. Kondisi ini sering menyebabkan terjadinya kerusakan pindang karena basi ataupun tumbuhnya jamur. Beberapa penelitian telah dilakukan sebagai upaya

\footnotetext{
") Peneliti pada Balai Besar Riset Pengolahan Produk dan Bioteknologi Kelautan dan Perikanan, DKP
} 
untuk memperpanjang daya awet ikan pindang, diantaranya penambahan rempah-rempah (Retnowati et al., 1984), arang (Subaryono et al., 2004), dan asam (Dwiyitno et al., 2005) selama proses pemindangan.

Kitosan merupakan produk turunan polimer kitin yang berasal dari limbah udang atau rajungan yang memiliki polikation bermuatan positif sehingga mampu menghambat pertumbuhan bakteri dan kapang (Anon., 2006). Beberapa peneliti telah mengaplikasikan kitosan untuk pengawetan produk pangan termasuk ikan asin (Hardjito, 2006), sedangkan percobaan penggunaaan kitosan untuk pengawetan ikan segar dan cumi segar ternyata kurang efektif (Hardjito, 2006; Murtini \& Kusmarwati, 2006). Untuk melihat efektivitas kitosan dalam pengawetan produk olahan ikan yang lain, maka dilakukan penelitian aplikasi kitosan untuk pengawetan ikan pindang.

\section{BAHAN DAN METODE}

\section{Bahan}

Bahan baku yang digunakan adalah ikan layang (Decapterus russelli) segar dengan bobot rata-rata 50 gram/ekor yang diperoleh dari TPI Pelabuhan Ratu hasil penangkapan satu hari melaut. Ikan layang tersebut dibawa ke laboratorium BBRP2B menggunakan jalan darat dalam peti berinsulasi yang berisi es dan langsung diolah pada pagi harinya. Bahan lain yang digunakan dalam penelitian ini antara lain garam rakyat yang dibeli dari penjual garam yang berlokasi di sekitar TPI Pelabuhan Ratu serta kitosan yang dibeli dari PT. Vital House Indonesia, Cirebon dengan spesifikasi : derajat deasetilasi $87,53 \%$ dan viskositas 5,2 cPs.

\section{Metode}

\section{Preparasi larutan kitosan}

Larutan stok kitosan dibuat dengan cara melarutkan kitosan sebanyak 1,5\% (b/v) dalam larutan asam asetat $1 \%$. Larutan stok tersebut kemudian diencerkan dengan akuades sehingga diperoleh larutan kitosan dengan konsentrasi 0,5 dan 0,25\%.

\section{Pemindangan}

Ikan layang segar disiangi dengan menghilangkan isi perut, kemudian dicuci dengan air bersih untuk menghilangkan kotoran dan sisa darah yang masih menempel pada ikan. Ikan layang yang telah bersih disusun dalam 'naya', diatasnya ditaburi garam sebanyak $7-8 \%$ dari bobot ikan kemudian 'naya' yang berisi ikan dicelupkan ke dalam air garam mendidih dengan konsentrasi $15 \%$ selama 15 menit. Selesai pencelupan,'naya' berisi ikan diangkat dan ditiriskan (Gambar 1).

Setelah tiris 'naya' berisi ikan tersebut dibagi menjadi 3 kelompok yang masing masing dicelupkan dalam larutan kitosan dengan konsentrasi berturutturut $0 ; 0,25$; dan $0,5 \%$ (b/v) selama 30 menit. Selesai perendaman, naya berisi ikan ditiriskan dan disimpan pada suhu kamar. Untuk melihat perubahan kualitas pindang selama penyimpanan, dilakukan pengambilan sampel setiap hari sampai pindang naya tersebut ditolak.

\section{Pengamatan}

Pengamatan terhadap sampel dilakukan secara organoleptik (kenampakan, bau, rasa, tekstur, dan

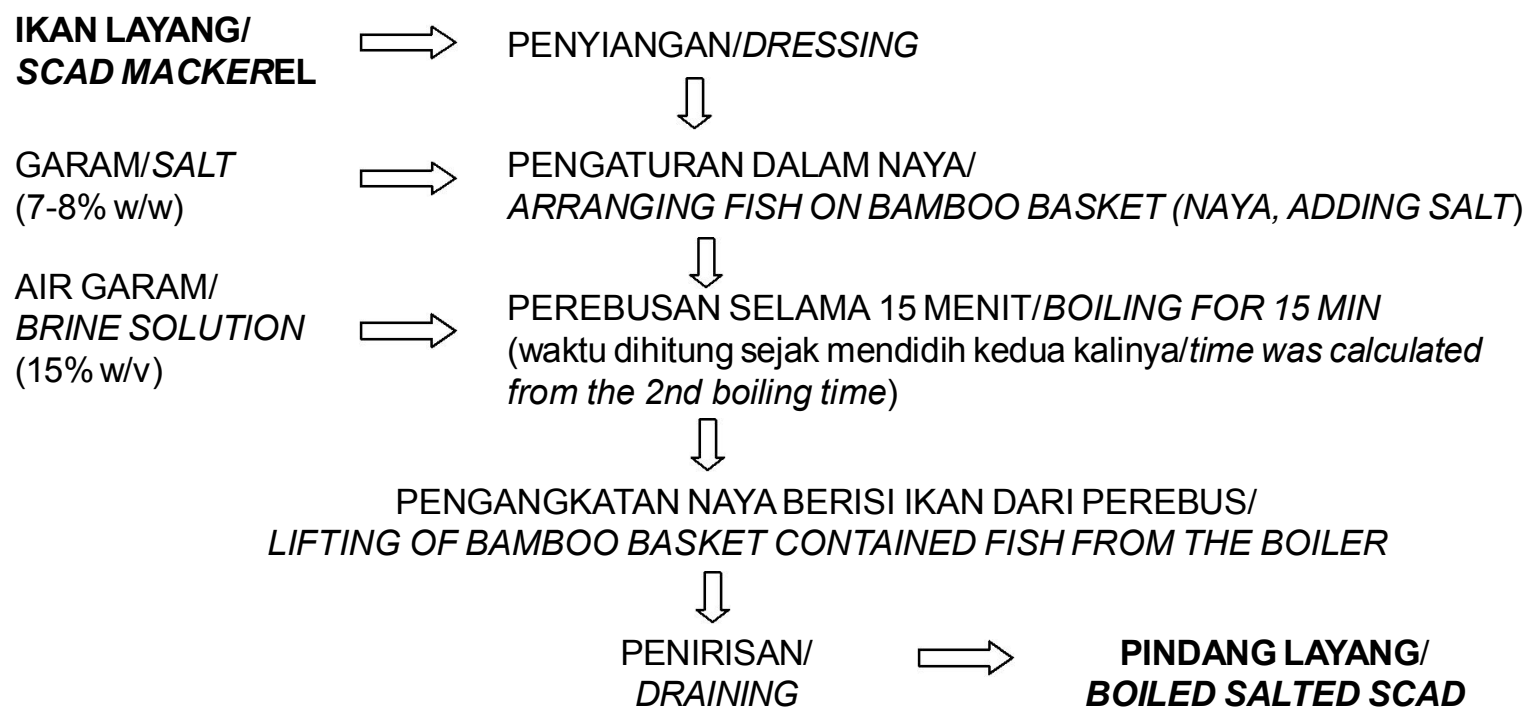

Gambar 1. Skema pembuatan pindang layang.

Figure 1. Schematic diagram of boiled salted scad processing. 
lendir), kimiawi (TVB dan proksimat untuk bahan baku dan pindang) dan mikrobiologi (TPC, bakteri pembentuk $\mathrm{H}_{2} \mathrm{~S}$ ). Penilaian sifat organoleptik pindang dilakukan dengan menggunakan lembar penilaian 5 tingkat untuk atribut kenampakan, bau, rasa, tekstur, dan lendir (Lampiran 1), analisis kadar TVB dilakukan dengan metode mikrodifusi Conway (Siang \& Kim, 1992), komposisi proksimat (air, abu, protein, lemak) dilakukan pada bahan baku dan produk pindang sebelum penyimpanan (AOAC, 1999), Analisis Total Plate Count (TPC) dilakukan dengan metode pour plate (SNI, 1991) dan analisis bakteri pembentuk $\mathrm{H}_{2} \mathrm{~S}$ dilakukan menurut metode Sumner (1981). Penelitian dilakukan menggunakan rancangan acak lengkap dengan 3 kali ulangan dan data hasil penelitian diolah menggunakan program Statistica Rel. 6.0 (StatSoft, Inc.).

\section{HASIL DAN BAHASAN}

Hasil analisis proksimat bahan baku dan produk pindang disajikan pada Tabel 1.

\section{Organoleptik}

Hasil penilaian secara organoleptik terhadap kenampakan/rupa pindang layang selama penyimpanan menunjukkan bahwa pindang yang direndam kitosan mempunyai nilai yang lebih tinggi dibandingkan dengan kontrol (Gambar 2).

Tabel 1. Hasil analisis proksimat bahan baku dan produk pindang ( $\% \mathrm{bb})$

Table 1. Result of proximate analysis of raw material and boiled salted fish (\% wb)

\begin{tabular}{lcccc}
\hline Jenis produk/Kind of product & Prote in & Lemak/Fat & Abu/Ash & Air/Moisture \\
\hline Layang segar/Fresh scad & 24.20 & 0.97 & 1.66 & 73.34 \\
Pindang layang/Boiled salted scad & 26.52 & 1.71 & 5.56 & 66.43 \\
\hline
\end{tabular}

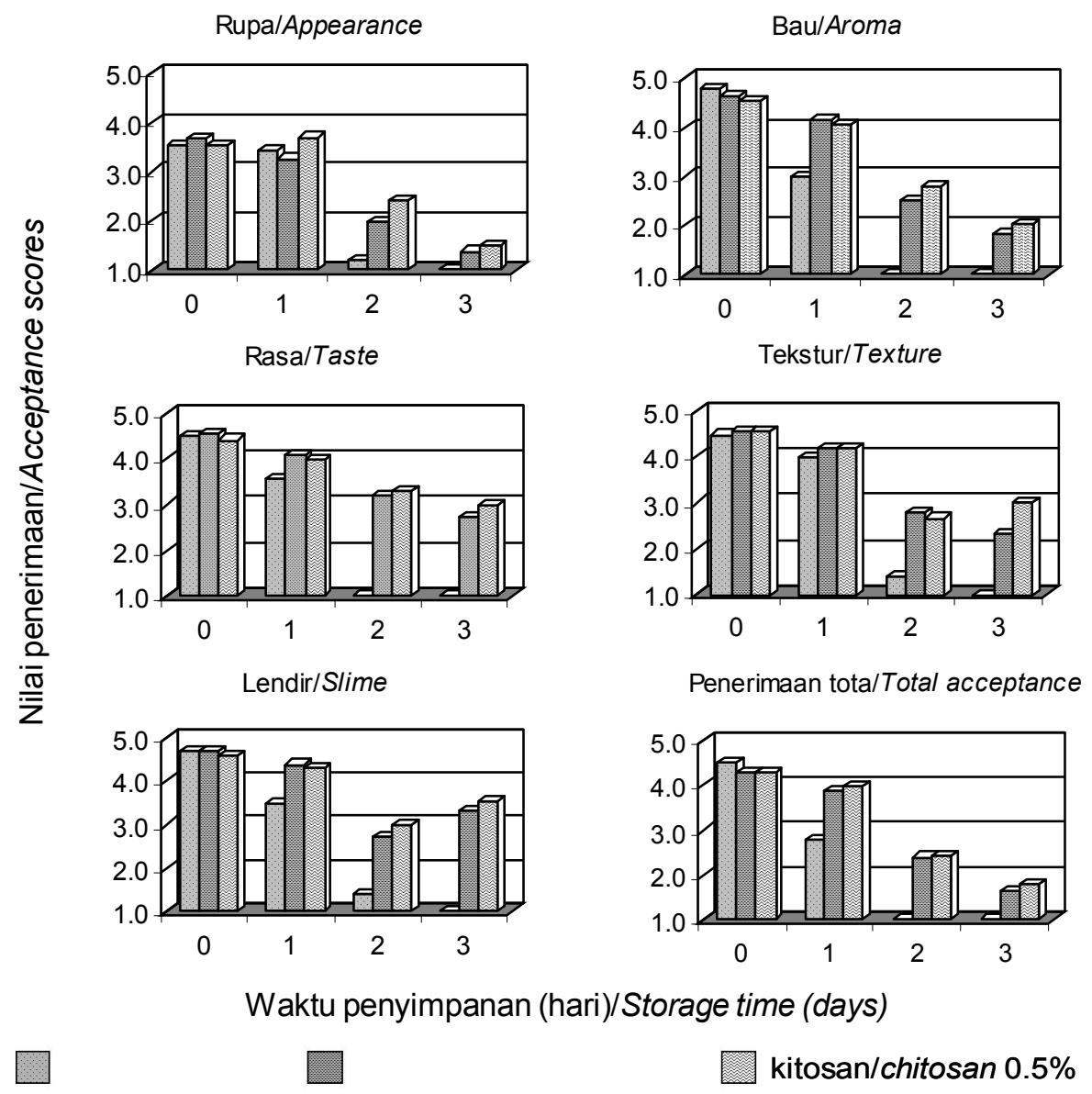

Gambar 2. Histogram nilai organoleptik pindang layang selama penyimpanan pada suhu kamar. Figure 2. Organoleptic scores of boiled salted scad mackerel during storage at ambient temperature. 
Pada penyimpanan hari ke-2, kenampakan pindang kontrol telah kotor, bau basi, dan tengik terdeteksi, lendir mulai kental dan berbau basi serta tekstur telah basah dan mulai berair, sehingga uji rasa tidak dilakukan, sedangkan pindang dengan perlakuan perendaman dalam kitosan masih diterima panelis. Sampai dengan penyimpanan hari ke-3, nilai atribut rasa, terbentuknya lendir dan tekstur pindang yang direndam kitosan relatif masih tinggi, tetapi nilai penerimaan total rendah. Berdasarkan penilaian panelis, perendaman dalam larutan kitosan tidak mempengaruhi rasa pindang, karena konsentrasi larutan kitosan yang digunakan dalam penelitian ini relatif kecil yaitu 0,25 dan $0,5 \%$, sementara larutan kitosan $0,75 \%$ yang digunakan untuk merendam cumi segar menyebabkan rasa cumi sepet dan pahit (Murtini \& Kusmarwati, 2006). Pengaruh larutan asam asetat sebagai pelarut kitosan pada rasa pindang juga tidak terdeteksi, karena konsentrasi larutan asam asetat yang digunakan dalam penelitian relatif kecil yaitu $0,04 \%$ untuk kitosan dengan konsentrasi $0,25 \%$ dan $0,08 \%$ untuk kitosan dengan konsentrasi $0,5 \%$.

Daya awet pindang layang kontrol pada penelitian ini tidak lama, hanya 1 hari. Hal ini disebabkan karena pindang kontrol direndam dalam air tanpa kitosan, sehingga diduga terjadi kontaminasi yang berasal dari air yang digunakan untuk merendam.

\section{Nilai TVB}

Pada awal sampai dengan 2 hari penyimpanan nilai TVB cenderung meningkat dengan nilai masih di bawah $100 \mathrm{mg} / 100 \mathrm{~g}$, dan pada penyimpanan hari ke-3 terjadi kenaikan secara nyata pada semua perlakuan (Gambar 3). Pada umumnya nilai batas penerimaan TVB untuk ikan segar adalah $30 \mathrm{mgN} /$ $100 \mathrm{~g}$ (Sikorski et al., 1990), sedangkan untuk ikan olahan dengan proses penggaraman nilai batas penerimaan TVB adalah $200 \mathrm{mgN} / 100 \mathrm{~g}$ (Connell, 1980). Meskipun demikian nilai ini juga tergantung pada jenis/spesies ikan. Meskipun telah melebihi batas penerimaan, pada penyimpanan hari ke 3 , nilai TVB pindang layang yang direndam kitosan hanya naik sampai dengan $225 \mathrm{mg} / 100 \mathrm{~g}$, sedangkan kontrol (tanpa perendaman) naik tajam sampai mencapai 423 $\mathrm{mg} / 100 \mathrm{~g}$. Hal ini berarti bahwa perendaman dengan kitosan dengan derajat diasetilasi $87,53 \%$ dan viskositas $5,2 \mathrm{cPs}$ mampu menekan terbentuknya TVB pada pindang layang sampai mencapai $50 \%$. Menurut Simpson et al. (1994), kitosan mempunyai sifat sebagai antimikrobial, dan dapat digunakan sebagai pengawet karena efektif menghambat $E$. coli dan Fusarium oxysporium (Hirano, 1989 dalam Hansen \& Illanes, 1994). Degradasi protein menjadi basa menguap seperti TVB, terutama disebabkan oleh aktivitas bakteri. Apabila pertumbuhan bakteri dihambat, maka laju peruraian protein menjadi komponen yang lebih rendah terutama TVB juga terhambat.

Dalam penelitian ini, kitosan yang digunakan adalah kitosan yang dilarutkan dalam asam asetat dan bukan kitosan larut air. Dengan demikian selain kitosan yang dapat menghambat aktivitas mikroorganisme, kemungkinan lain sebagai penyebab penghambatan aktivitas mikroba adalah sifat asam dari asam asetat sebagai pelarut kitosan. Asam asetat diketahui sebagai bahan pengawet yang dapat menghambat aktivitas mikroorganisma melalui penetralan gradien elektrokimia dari membran sel dan

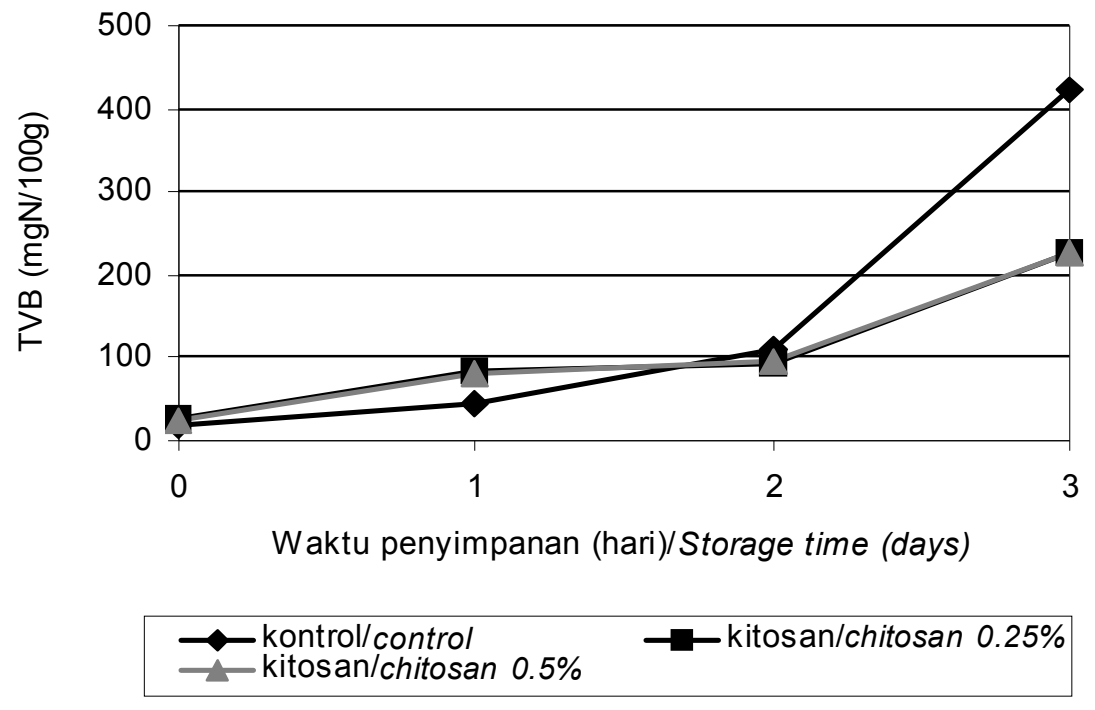

Gambar 3. Perubahan nilai TVB pindang layang selama penyimpanan pada suhu kamar.

Figure 3. Changes of TVB value of boiled salted scad mackerel during storage at ambient temperature. 
juga melalui denaturasi protein dalam sel mikroorganisme (Ray, 2001). Meskipun demikian pada perlakuan dalam penelitian ini tidak dilakukan kontrol negatif yaitu larutan asam asetat saja tanpa kitosan sebagai larutan perendam.

\section{Kadar air}

Berdasarkan hasil analisis, kadar air pindang layang sampai dengan 2 hari penyimpanan cenderung konstan. Pada umumnya kadar air pindang berkisar 60-66\% (Retnowati et al., 1884; Ariyani et al., 2004; Subaryono et al., 2004; Dwiyitno et al., 2005). Kadar air pindang dalam penelitian ini relatif lebih tinggi (70$71 \%$ ) karena adanya perlakuan perendaman dalam air ataupun kitosan sebelum penyimpanan. Pada penyimpanan 3 hari kadar air menurun tajam untuk pindang yang direndam kitosan, sedangkan kadar air kontrol sedikit menurun. Kitosan merupakan bahan yang sangat mudah menyerap air, dengan demikian adanya lapisan kitosan pada permukaan pindang menyebabkan terjadinya proses penyerapan air oleh kitosan selama penyimpanan.

\section{Mikrobiologi}

Perubahan jumlah bakteri total dan jumlah bakteri pembentuk $\mathrm{H}_{2} \mathrm{~S}\left(\mathrm{BPH}_{2} \mathrm{~S}\right)$ pada pindang layang selama penyimpanan seperti terlihat pada Gambar 5 dan Gambar 6. Berdasarkan analisis statistik, perendaman pindang dalam larutan kitosan ternyata memberikan perbedaan pada nilai TPC maupun $\mathrm{BPH}_{2} \mathrm{~S}$. Pada penyimpanan 1 hari, pindang layang yang direndam kitosan 0,25 dan $0,5 \%$ ternyata menunjukkan nilai
TPC dan $\mathrm{BPH}_{2} \mathrm{~S}$ yang relatif lebih kecil dibandingkan dengan kontrol. Hal ini menunjukkan bahwa kitosan mampu menghambat pertumbuhan bakteri pada pindang layang yang disimpan pada suhu kamar. Apabila dilihat dari waktu penyimpanannya, semakin lama waktu penyimpanan, nilai TPC maupun $\mathrm{BPH}_{2} \mathrm{~S}$ semakin tinggi dengan kecepatan pertumbuhan yang relatif konstan. Meskipun demikian, pindang layang yang direndam kitosan 0,5\% mempunyai nilai TPC dan $\mathrm{BPH}_{2} \mathrm{~S}$ yang relatif lebih rendah dibanding kontrol maupun pindang yang direndam kitosan $0,25 \%$.

Menurut Muzzarelli (1990), kitosan dan turunannya lebih efektif sebagai anti bakteri. Meskipun mekanisme penghambatan terhadap aktivitas bakteri belum jelas, tetapi beberapa hal yang diperkirakan merupakan penyebab penghambatan antara lain: penghilangan ion penting (misalnya $\mathrm{Cu}$ ) pada mikroorganisme, sehingga mengganggu sistem keseimbangan yang melibatkan ion logam dimaksud yang dapat berakhir dengan kematian bakteri; kitosan mempunyai kemampuan untuk merusak atau memblokade fungsi membran pada sel bakteri; kitosan dapat menyebabkan kebocoran pada komponen intraseluler; kitosan mampu membentuk polielektrolit komplek dengan polimer yang bersifat asam pada permukaan sel bakteri (Muzzarelli, 1977; Muzzarelli et al., 1990; Simpson et al., 1994; Ray, 2001). Sebagaimana mekanisme penghambatan dalam pembentukan TVB oleh aktivitas bakteri, selain karena kitosan sebagai antibakteri, kemungkinan lain terjadinya penghambatan aktivitas bakteri disebabkan oleh asam asetat sebagai pelarut kitosan. Menurut Ray (2001), asam asetat dengan konsentrasi $0,02 \%$

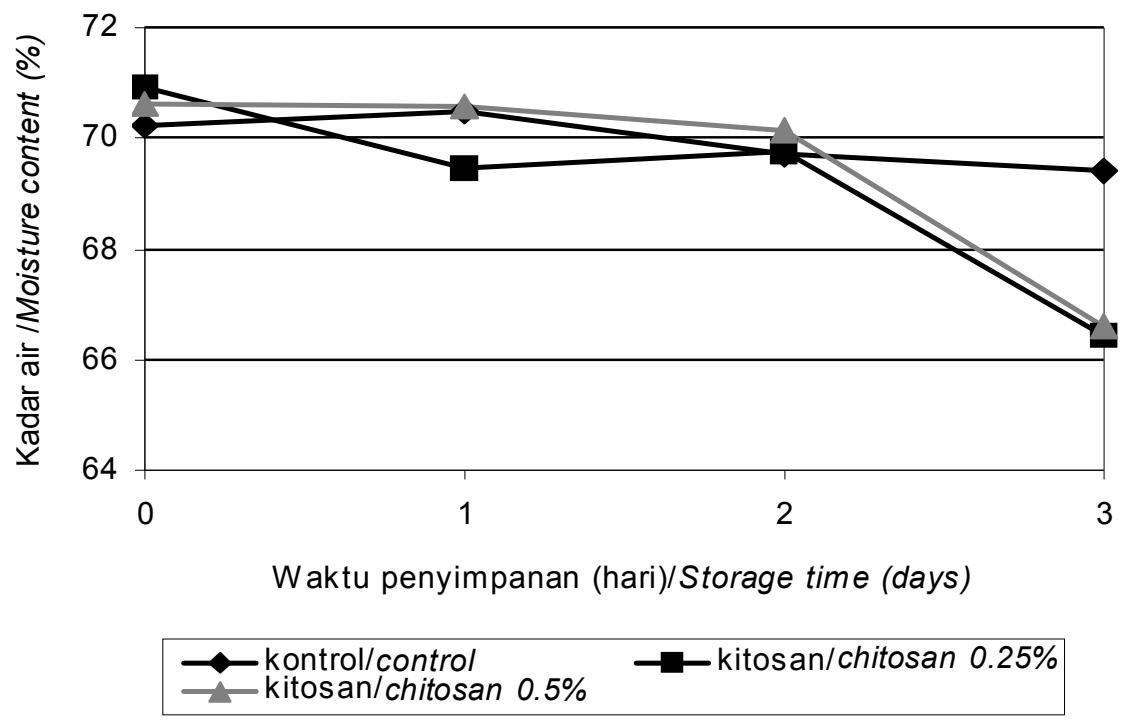

Gambar 4. Perubahan kadar air pindang layang selama penyimpanan pada suhu kamar.

Figure 4. Moisture content changes of of boiled salted scad mackerel during storage at ambient temperature. 


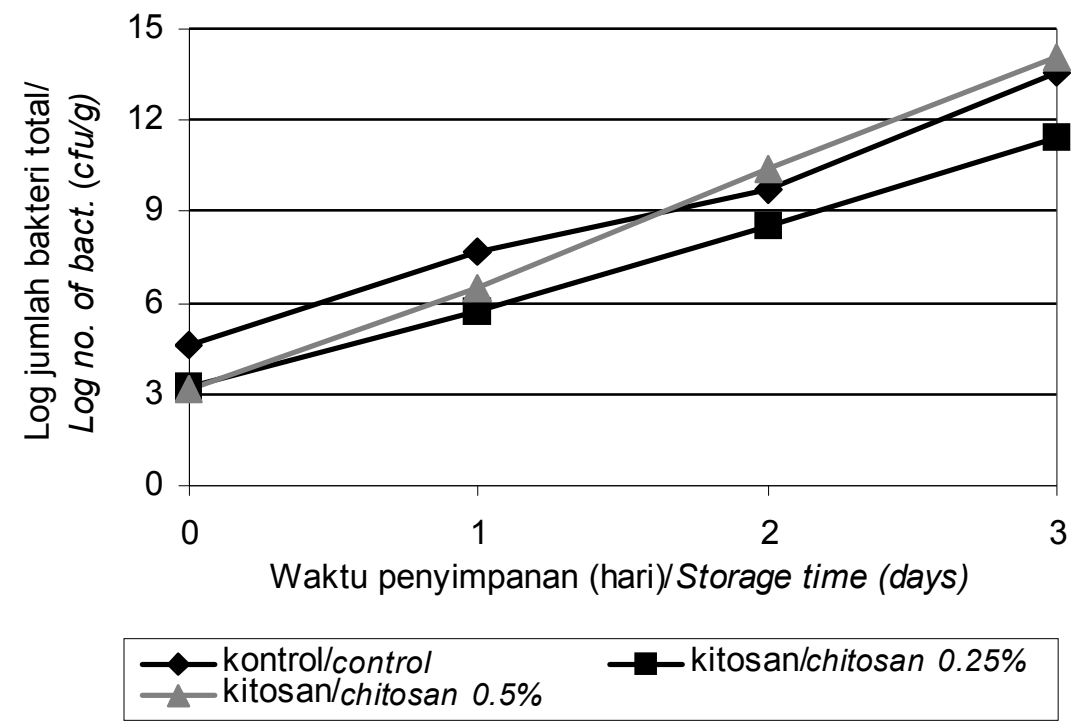

Gambar 5. Perubahan jumlah bakteri total pindang layang selama penyimpanan pada suhu kamar.

Figure 5. Changes of total plate count value of boiled salted scad mackerel during storage at ambient temperature.

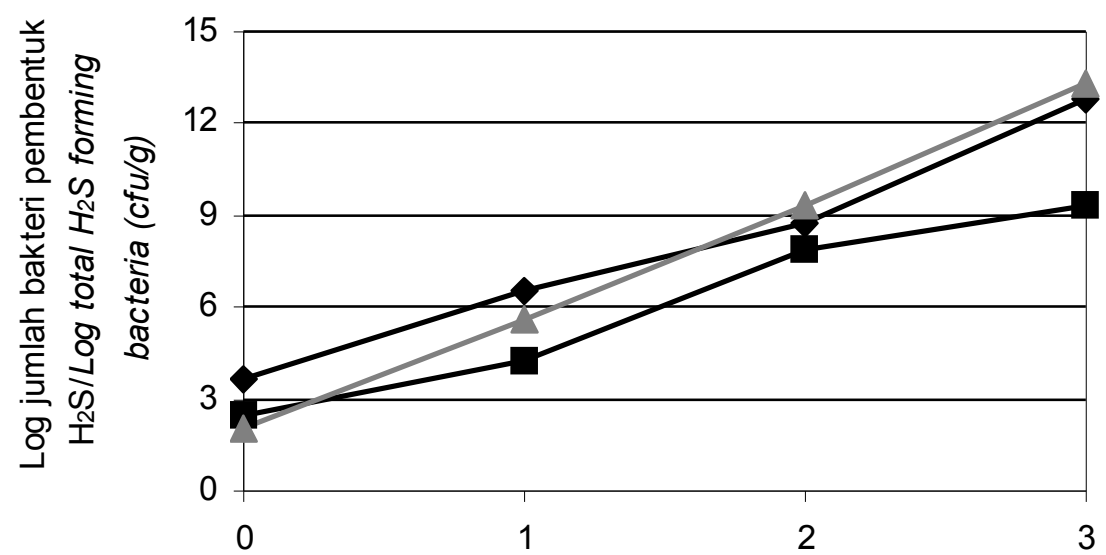

Waktu penyimpanan (hari)/Storage time (days)

k kontrol/control
- kitosan/chitosan $0.5 \%$

Gambar 6. Perubahan jumlah bakteri pembentuk $\mathrm{H}_{2} \mathrm{~S}$ pindang layang selama penyimpanan pada suhu kamar.

Figure 6. Changes of number of $\mathrm{H}_{2} \mathrm{~S}$ forming bacteria of boiled salted scad mackerel during storage at ambient temperature.

dapat menghambat Salmonella spp. dan B. cereus, pada konsentrasi $0,01 \%$ dapat menghambat $S$. aureus dan pada konsentrasi $0,1-0,5 \%$ dapat menghambat Aspergillus spp. dan Saccharomyces spp.

\section{KESIMPULAN}

Berdasarkan hasil percobaan penggunaan kitosan untuk mengawetkan pindang layang, dapat disimpulkan bahwa :
- Larutan kitosan dalam asam asetat mempunyai potensi untuk memperpanjang daya awet ikan pindang

- Pada penyimpanan suhu kamar, daya awet pindang yang direndam larutan kitosan $0,25 \%$ (dalam larutan asam asetat 0,04\%) dan larutan kitosan $0,5 \%$ (dalam larutan asetat 0,08\%) adalah 3 hari, sedangkan daya awet pindang kontrol 1 hari.

- Aplikasi kitosan larut air sebagai pengawet produk perikanan perlu dicoba untuk mengetahui 
apakah kitosan tanpa bersinergi dengan asam sebagai pelarutnya tetap dapat diaplikasikan sebagai bahan pengawet produk perikanan olahan.

\section{DAFTAR PUSTAKA}

Anonim. 2006. Statistik Perikanan Tangkap Indonesia 2004. Direktorat Jenderal Perikanan Tangkap. Departemen Kelautan dan Perikanan, Jakarta. 58 pp.

Anonymous. 2006. Chitosan: Manufacture and properties. http://en.wikipedia.org/wiki. chitosan. Diakses tanggal 13 Oktober 2008. 4 pp.

AOAC, 1999. Official Methods of Analysis, 13th ed. Method no. 24.046. Association of Official Analytical Chemists. Washington, D.C.

Ariyani, F., Yulianti, dan Martati, T. 2004. Studi perubahan kadar histamin pada pindang tongkol (Euthynnus affinis) selama penyimpanan. J. Penel. Perik. Indonesia. Edisi Pasca Panen. 10(3): 35-46.

Connell, J.J. 1980. Control of Fish Quality: 4. Quality Deterioration and Defects in Products. England. Fishing New Books Ltd. p. 56-105.

Dwiyitno, Ariyani, F., Kusmiyati, T., dan Harmita. 2005. Perlakuan perendaman dalam larutan asam untuk menghambat perkembangan histamin pada pindang ikan lisong (Scomber australasicus CV). J. Penel. Perikanan Indonesia. 11(8): 1-8.

Gopakumar, 1997. Tropical Fishery Products: Some Traditional Dried and Smoke Cured Products. New Hampshire. Sci. Publ., Inc. p. 14-67.

Hansen, M.E. and Illanes, A. 1994. Applications of crustacean wastes in biotechnology. In Martin, A.M. (ed.). Fisheries Processing. Biotechnological Applications. Chapman \& Hall, London. p. 174-205.

Hardjito, L. 2006. Aplikasi kitosan sebagai bahan tambahan makanan dan pengawet (application of chitosan as food additive and preservation). In Santoso, J., Trilaksani, W., Nurhayati, T., dan Suseno, S.H. (eds.). Prosiding Seminar Nasional Kitin-Kitosan 2006. Prospek produksi dan aplikasi kitin-kitosan sebagai bahan alami dalam membangun kesehatan masyarakat dan menjamin keamanan produk. Departemen Teknologi Hasil Perairan, Fakultas Perikanan dan IImu Kelautan, IPB, Bogor. p. 1-13.

Heruwati, E.S., Indriati, N., Ariyani, F., Yeni, Y., Riyanto, R., Priyanto, N., Murtini, J.T., Arifah, K., Rachmawati, N., dan Siregar, T.S. 2006. Riset keamanan pangan produk perikanan selama penanganan dan pengolahan. Laporan Teknis. Bagian Proyek Riset
Pengolahan Produk dan Sosial Ekonomi Kelautan dan Perikanan, Jakarta.

Murtini, J.T. dan Kusmarwati, A. 2006. Pengaruh perendaman cumi-cumi segar dalam larutan kitosan terhadap daya awetnya selama penyimpanan pada suhu kamar. JPB Perikanan. 1(2): 157-161.

Muzzarelli, R. 1977. Chitin Handbook. Oxford, UK. Pergamon Press. 309 pp.

Muzzarelli, R., Tarsi, R., and Filipini, O. 1990. Antimicrobial properties of $\mathrm{N}$-carboxymethyl chitosan. Antimicrob. Agents Chemother. 34: 2019-2023.

Nasran. 1980. Present Status dalam Usaha Pemindangan. In llyas, S. dan Nasran, S. (eds.). Teknologi Pengolahan Pindang. Lembaga Penelitian Teknologi Perikanan, Badan Litbang Pertanian, Departemen Pertanian, Jakarta. p. 1-17.

Ray, B. 2001. Fundamental Food Microbiology. London, CRC Press. 562 pp.

Retnowati, N., Murniyati, dan Nasran, S. 1984. Studi penggunaan rempah-rempah guna memperpanjang daya awet pindang. Laporan Penelitian Teknologi Perikanan. (29): 11-19.

Siang, N.C. and Kim, L.L. 1992. Determination of Trimethylamine Oxide (TMAO-N), Trimethylamine (TMA-N), Total Volatile Basic Nitrogen (TVB-N) by Conway's microdiffusion method. (1\% boric acid and $0.02 \mathrm{~N}$ hydrochloric acid). In Miwa, K. and Ji, L.S. (eds.). Laboratory Manual on Analytical Methods and Procedures for Fish and Fish Products. 2nd. Marine Fish. Res, Dep., SEAFDEC, Singapore. p. B-8.1-B8.5

Sikorski, Z.E., Kolakowska, A., and Burt, J.R. 1990. Postharvest biochemical and microbial changes. In Sikorski, Z.E. (ed.). Seafood: Resources, Nutritional Composition and Preservation. CRC Press Inc., Boca Raton, FL. p. 55-75.

Simpson, B.K., Gagne, N., and Simpson, M.V. Bioprocessing of chitin and chitosan. 1994. In Martin, A.M. (ed.). Fisheries Processing. Biotechnological Applications. Chapman \& Hall, London. p. 156-173.

SNI 01-2339. 1991. Metode Pengujian Mikrobiologi Produk Perikanan. Penentuan Total Aerobic Plate Count (TPC). Dewan Standardisasi Nasional, Jakarta. p. 1-2.

Subaryono, Ariyani, F., dan Dwiyitno. 2004. Penggunaan arang untuk mengurangi kadar histamin ikan pindang tongkol batik (Euthynnus affinis). J. Penel. Perik. Indonesia. Edisi Pasca Panen. 10(3): 27-34.

Sumner, J. (1981). Advanced Fish Microbiology. Methods for Detecting Organisms of Public Health Significance. RMIT, Melbourne, Australia. 28 pp. 
LAMPIRAN 1/APPENDIX 1

\section{LEMBAR PENILAIAN ORGANOLEPTIK IKAN PINDANG/ SCORE SHEET FOR SENSORY ASSESSMENT OF BOILED SALTED FISH}

\begin{tabular}{|c|c|c|}
\hline $\begin{array}{l}\text { Faktor yang dinilai/ } \\
\text { Factors to be } \\
\text { assessed }\end{array}$ & Diskripsi/Description & $\begin{array}{c}\text { Kode sampel/ } \\
\text { Sample code }\end{array}$ \\
\hline \multirow{6}{*}{$\begin{array}{l}\text { Kenampakan/ } \\
\text { Appearance }\end{array}$} & 5- utuh, bersih, rapi, menarik/whole, clean, bright, & \\
\hline & $\begin{array}{l}\text { attractive } \\
\text {. }\end{array}$ & \\
\hline & $\begin{array}{l}\text { 4- utuh, kurang rapi, bersih, menarik/whole, less bright, } \\
\text { clean, attractive }\end{array}$ & \\
\hline & 3- ada bagian yang pecah/some parts broken & \\
\hline & 2- agak kotor/slightly dirty & \\
\hline & 1- kotor/dirty & \\
\hline \multirow[t]{5}{*}{ Bau/Odor } & $\begin{array}{l}\text { 5- harum, segar dan enak/odoriferous, freshly cooked, } \\
\text { delicious }\end{array}$ & \\
\hline & 4- enak, kurang gurih/delicious, less tasty & \\
\hline & $\begin{array}{l}\text { 3- agak bau asam, agak tengik, kurang enak/slightly sour, } \\
\text { slightly rancid, less delicious }\end{array}$ & \\
\hline & 2- tidak enak, tengik, basi/not delicious, rancid, stale & \\
\hline & 1- tengik dan busuk/rancid and spoiled & \\
\hline \multirow[t]{5}{*}{ Rasa/Taste } & 5- enak, gurih, tidak gatal/delicious, tasty, not itchy & \\
\hline & $\begin{array}{l}\text { 4- enak, kurang gurih, tidak gatal/delicious, less tasty, not } \\
\text { itchy }\end{array}$ & \\
\hline & 3- hampir tawar, agak gatal/ nearly plain, slightly itchy & \\
\hline & 2- tidak enak, rasa basi, gatal/not delicious, stale, itchy & \\
\hline & 1- busuk, gatal sekali/spoiled, very itchy & \\
\hline \multirow[t]{5}{*}{ Tekstur/Texture } & 5- utuh, padat, kompak/whole, solid, compact & \\
\hline & 4- retak-retak, padat, kompak/cracking, solid, compact & \\
\hline & 3- agak berair, longgar, rapuh/slightly moist., loose, fragile & \\
\hline & 2- basah, berair/wet, moist & \\
\hline & $\begin{array}{l}\text { 1- lengket, basah, mudah terurai/sticky, wet, easily } \\
\text { decompose }\end{array}$ & \\
\hline \multirow[t]{5}{*}{ Lendir/Slime } & 5- tidak berlendir/no slime & \\
\hline & $\begin{array}{l}\text { 4- lendir tipis, tidak jelas, tidak berbau/slime thin, not } \\
\text { transparent, not smelly }\end{array}$ & \\
\hline & 3- lendir agak kental/slime slightly viscous & \\
\hline & 2- lendir basi/slime stale & \\
\hline & 1- lendir busuk/slime spoiled & \\
\hline \multirow{5}{*}{$\begin{array}{l}\text { Penerimaan total/ } \\
\text { Total acceptance }\end{array}$} & 5- sangat suka/very like & \\
\hline & 4- suka/like & \\
\hline & 3- agak suka/slightly like & \\
\hline & 2- tidak suka/dislike & \\
\hline & 1- sangat tidak suka/dislike very much & \\
\hline
\end{tabular}

